\title{
ОСВИДЕТЕЛЬСТВОВАНИЕ И ЕГО РОЛЬ В РАСКРЫТИИ УБИЙСТВ, СОВЕРШЕННЫХ ПО РЕЛИГИОЗНЫМ МОТИВАМ
}

\section{INSPECTION AND ITS ROLE IN DISCLOSURE OF MURDERS COMMITTED WITH THE RELIGIOUS GROUNDS}

D. Ryabinin

Summary. In this article the meaningful issues, related to the role of inspection (examination) in investigation and disclosure (detection) of murders, committed with the religious grounds, are addressed. The attention is paid to the consideration of the character of specific features/signs on the human body evidencing his/her attribution to a specific religious group or his/her adherence to specific religious beliefs. The author's definition of the inspection, made in connection with the considered category of crimes, is formulated.

Keywords: inspection, murder, religious group, religious ground, religious symbols, tattoo.

\author{
Рябинин Дмитрий Александрович \\ Старший следователь по особо важным \\ делам, Главное военное следственное управление \\ Следственного комитета Российской Федерации, \\ 2. Москва \\ rabinyn@intmail.net
}

Аннотация. В настоящей статье освещаются актуальные вопросы, связанные с ролью освидетельствования в раскрытии и расследовании убийств, совершенных по религиозным мотивам. Уделяется внимание рассмотрению характера особых примет на теле человека, свидетельствующих о его принадлежности к конкретной религиозной группе или его приверженности определенным религиозным взглядам. Формулируется авторская дефиниция понятия освидетельствования, проводимого по рассматриваемой категории преступлений.

Ключевые слова: освидетельствование, убийство, религиозная группа, религиозный мотив, религиозная символика, татуировки.

экспертизы [1]. В криминалистике освидетельствование рассматривается в качестве особого вида следственного осмотра, отличающегося целым комплексом особенностей процессуального характера.

Основанием для проведения указанного следственного действия по рассматриваемой категории преступлений могут служить любые объективные данные, свидетельствующие о возможном наличии на теле фигуранта по делу (подозреваемого, обвиняемого, свидетеля), в отношении которого имеются сведения о его принадлежности к той или иной деструктивной религиозной организации, признаков, примет или особенностей, позволяющих сделать вывод о его вероятной причастности к произошедшему преступному событию.

Перед проведением освидетельствования по делам об убийствах, обусловленных религиозной мотивацией, следователь решает следующие характерные тактические задачи, связанные с:

- определением лица, которое будет проводить освидетельствование (необходимо учитывать, что следователь должен быть одного пола с освидетельствуемым, если оно сопровождается обнажением частей тела);

- привлечением, в случае необходимости, понятых одного пола с освидетельствуемым; 
- необходимостью привлечения к проведению освидетельствования специалистов (врача, судебно-медицинского эксперта, эксперта-криминалиста, специалиста в области религиозных культов и т.д.);

- необходимостью принятия мер для принудительного проведения следственного действия в связи с возможным отказом освидетельствуемого от его проведения (такой сценарий наиболее прогнозируем при освидетельствовании членов религиозных культов).

Особую значимость для следователя при освидетельствовании адептов религиозных культов будут представлять не только имеющиеся на их теле характерные телесные повреждения (ссадины, укусы и т.п.), аномалии анатомического строения (например, «заячья губа», горб, сильное искривление позвоночника, отсутствие нескольких пальцев и т.п.) и функционального характера (особенности походки, жестикуляции, мимики), но и такие особые приметы, как шрамы, следы травм, татуировки в виде символов и знаков, а также иные следы, которые могут свидетельствовать о принадлежности лиц к той или иной религиозной группе или их приверженности определенным религиозным доктринам.

Татуировки или рисунки религиозных символов и знаков, наносимые путем накалывания или втирания под кожу красящих веществ, представляют собой, в большинстве случаев, уникальную религиозную символику (например, в виде буквенно-цифровых сочетаний: «Lucifer», «666», «13», в виде рисунков, изображающих падших ангелов, чертей, пентаграммы и т.п.), имеющую определенное значение для верующих, и располагаются, как правило, в верхней части туловища, нередко на верхних конечностях сектантов. Они демонстрируют не только серьезную приверженность их обладателя сложившейся системе взглядов, но и имеют для верующего духовное значение, формируют у него чувство собственной принадлежности к религиозной группе, идентичности с ней.

Наиболее наглядно иллюстрируют изложенное следующие примеры из судебно-следственной практики.

Так, в частности, татуировка в виде пятиконечной перевернутой звезды («пентаграмма») с надписью на латинском языке, свидетельствующая об увлечении ее обладателя оккультно-мистическим учением в виде поклонения «сатане», была обнаружена в ходе освидетельствования в верхней трети левого плеча С., обвиняемого в совершении ритуального убийства [7].

На щиколотках фигурантов по уголовному делу 3., К. и К-на, совершивших убийства на почве религиозной ненависти, имелись татуировки в виде перевернутого христианского креста - знака принадлежности к религиозному культу Сатаны. У обвиняемого 3., кроме того, на руке имелась татуировка в виде трех шестерок («666»- число Сатаны) [3, с. 57; 4, с. 290].

При освидетельствовании сатаниста Л. на его груди был обнаружен вырезанный лезвием символ «666» [4, с. 190]. Аналогичный символ был вытатуирован на правом запястье Ш., которая, находясь в православном храме, руководствуясь мотивом религиозной ненависти по отношению к православным священнослужителям, используя огнестрельное оружие, угрожала убийством присутствовавшему в храме священнику [8].

Членов радикальных исламских религиозных организаций можно идентифицировать, в ряде случаев, по наличию у них на различных частях тела татуировок на арабском языке (в традиционном исламе татуирование тела запрещено).

Следует говорить о том, что большинство подобных изображений на теле адептов религиозных культов в виде рисунков, геометрических фигур, чисел и т.д. имеют коллективно распознаваемое значение и ясно указывают на определенные верования и взгляды человека, вследствие чего способствуют идентификации преступника. В необходимых случаях, для определения значения имеющихся на теле фигуранта изображений религиозных символов и знаков представляется целесообразным получение консультации у специалистов в области религиоведения и религиозных культов или назначение по делу судебной искусствоведческой экспертизы.

Проведение освидетельствования необходимо и в тех случаях, когда следователь получает информацию (от свидетелей, экспертов, специалистов и др.) о практикующихся в религиозной группе изуверских религиозных обрядах, связанных с нанесением характерных телесных повреждений, свидетельствующих об участии в них членов культа и их принадлежности к такому культу. Так, например, члены секты «мурашковцев» при приеме в секту наносят своим приверженцам «семь печатей святого духа», представляющие собой глубокие крестообразные надрезы на коже. В секте «скопцов» проводится обряд полного или частичного оскопления (кастрации) верующих [5, с. 142], что связано с идеями искупления и покаяния. Кастрирование мужчин также было зафиксировано среди адептов секты американского происхождения «Небесные Врата», что являлось методом контроля их половых влечений [6, с. 318].

Характер телесных повреждений у членов религиозных культов определяется направленностью их религиозных убеждений, а также сложившейся ритуальной прак- 
тикой, в которую включены действия по их причинению. Наиболее часто действия, связанные с причинением телесных повреждений верующим, используются в обрядах по инициации адептов, при изменении их социального статуса и роли в группе (например, занятие руководящей должности), где им придается символический смысл.

Bсе особые приметы, обнаруженные на теле верующего в ходе освидетельствования, должны быть тщательно описаны в соответствующем протоколе (форма, размер и место расположения, содержание рисунка или текста, цвет красителя) и по возможности зафиксированы (при помощи фото-, видеосъемки) крупным планом для последующего направления, в случае необходимости, вместе с материалами уголовного дела для производства консультаций у специалистов или проведения экспертизы.

В науке до настоящего времени спорным является вопрос включения в задачу освидетельствования определения наличия у освидетельствуемого состояния опьянения.

Общеизвестно, что сектанты нередко совершают противоправные действия, находясь в состоянии алкогольного или наркотического опьянения, при этом, учитывая то, что внешним осмотром тела человека выявить наличие у него состоянии алкогольного опьянения невозможно, представляется необходимым для выявления такого состояния у лица назначать проведение судебно-медицинской экспертизы в соответствии с требованиями главы 27 УПК РФ.

Освидетельствование, как следственное действие, по нашему мнению, не предполагает ни осмотра, ни изъятия личных вещей и предметов одежды обследуемого верующего, которые нередко свидетельствуют о его принадлежности к определенной религиозной группе (одежда с соответствующими символами и знаками религиозного содержания, балахоны определенного цвета и т.п.), а также могут иметь на себе следы преступления. По общему правилу такие вещи должны изыматься в ходе личного обыска с целью их последующего осмотра и принятия решения о приобщении к материалам уголовного дела в качестве вещественных доказательств.

Вместе с этим, ряд ученых отмечает, что «освидетельствование может сопровождаться осмотром и должно производиться в определенной последовательности: сначала осматриваются части тела, не закрытые одеждой, затем при необходимости - одежда, а потом остальные части тела» [2, с. 561]. Однако в данном случае следует оговориться, что речь идет не о полном доскональном осмотре одежды, а об установлении факта соотношения следов, имеющихся на теле человека и его одежде, друг с другом путем проведения соответствующих сопоставлений.

Важно иметь в виду, что во время проведения освидетельствования члена религиозной группы категорически нельзя: допускать действия, реплики, которые унижают достоинство освидетельствуемого лица; проводить осмотр тела продолжительное время или осматривать части тела, которые в данном случае оголяться не должны; совершать действия, которые влекут причинение освидетельствуемому боли, могут быть расценены верующим как святотатство, нарушение свободы его вероисповедания, оскорбление его религиозных чувств и т.п.

Служебное помещение, в котором будет производиться освидетельствование члена религиозного культа, должно быть предварительно осмотрено на предмет отсутствия в нем предметов культового назначения, содержащих религиозную символику, способных вызвать негативную реакцию верующего.

Проведенное изучение поставленной проблемы дает основание для изложения дефиниции понятия освидетельствования с учетом его специфики по изучаемой категории преступлений. Тем самым, под освидетельствованием по делам об убийствах, совершенных по религиозным мотивам, следует понимать неотложное следственное действие, заключающееся в визуальном восприятии следователем, иным полномочным субъектом поисково-познавательной деятельности или лицом, обладающим специальными познаниями в области медицины, тела подозреваемого (обвиняемого) в совершении религиозно мотивированного убийства или свидетеля по делу с его согласия в целях установления следов преступления, наличия характерных телесных повреждений и особых отличительных примет знаково-символического характера, имеющих религиозное значение, признаков профессиональной принадлежности, выявления состояния опьянения, а также иных свойств и признаков, представляющих значение для дела и свидетельствующих о возможной принадлежности обследуемого лица к конкретной религиозной группе или позволяющих судить о возможной причастности освидетельствуемого к совершению преступления или его связи с преступным событием.

Подводя итог сказанному, можно прийти к выводу о том, что знание субъектами поисково-познавательной деятельности характерных особенностей производства освидетельствования по рассматриваемой категории преступлений способствует не только получению важной доказательственной информации, но и установлению возможной мотивации преступного поведения и, как следствие, успешному производству предварительного следствия по делу. 


\section{ЛИТЕРАТУРА}

1. Уголовно-процессуальный кодекс Российской Федерации от 18 декабря 2001 г. № 174-Ф3 (ред. от 27.12.2019) // Собрание законодательства Российской Федерации. - 2001.— № 52 (ч. 1).—- С. 4291.

2. Аверьянова Т. В. Криминалистика: учеб. / Т. В. Аверьянова, Р. С. Белкин, Ю. Г. Корухов, Е. Р. Россинская. 4-е изд., перераб. и доп. - М.: ИНФРА-М, 2013.$928 \mathrm{c}$.

3. Брежнева Г. В. Убийство на почве религиозной ненависти. Сборник «Следственная практика». Выпуск № 4 (165). - М: Издательство НИИ проблем укрепления законности и правопорядка Генеральной прокуратуры РФ, 2004. - 312 с.

4. Воробьевский Ю. Ю. Путь в Апокалипсис: Шаг змеи. - М., 1999. - 524с.

5. Мишин Н.Я. Установление фактов, свидетельствующих о преступном посягательстве на личность и права граждан под видом исполнения религиозных обрядов. Статьи аспирантов // Труды: Статьи аспирантов. Труды ВЮзИ.— М.: РИО ВЮзИ, 1967. Т. 11. — 244 с.

6. Dawn Perlmutter. Investigating religious terrorism and ritualistic crimes. Boca Raton, London, New York, Washington, D.C., 2004.— 320 p.

7. Уголовное дело № 2-18/2009 (архив Верховного Суда Республики Хакасия).

8. Уголовное дело № 1-1427/02 (архив Преображенского районного суда города Москвы).

(с) Рябинин Дмитрий Александрович ( rabinyn@intmail.net). 